Piracy in World History 


\section{Maritime Humanities, 1400-180o: Cultures of the Sea}

Early modern oceans not only provided temperate climates, resources, and opportunities for commercial exchange, they also played a central role in cultural life. Increased exploration, travel, and trade, marked this period of history, and early modern seascapes were cultural spaces and contact zones, where connections and circulations occurred outside established centres of control and the dictates of individual national histories. Likewise, coastlines, rivers, and ports were all key sites for commercial and cultural exchange. Interdisciplinary in its approach, Maritime Humanities, 1400-180o: Cultures of the Sea publishes books that conceptually engage with issues of globalization, postcolonialism, eco-criticism, environmentalism, and the histories of science and technology. The series puts maritime humanities at the centre of a transnational historiographical scholarship that seeks to transform traditional land-based histories of states and nations by focusing on the cultural meanings of the early modern ocean.

Series Editors: Claire Jowitt and John McAleer

Advisory Board Members: Mary Fuller, Fred Hocker, Steven Mentz, Sebastian Sobecki, David J. Starkey, and Philip Stern 


\title{
Piracy in World History
}

\author{
Edited by \\ Stefan Eklöf Amirell \\ Bruce Buchan, and \\ Hans Hägerdal
}


Cover illustration: Daniel Boyd, 'We Call them Pirates Out Here', 2006, oil on canvas, $226 \times 276 \mathrm{~cm}$. This image is reproduced courtesy of the artist and Roslyn Oxley9 Gallery, Sydney.

Cover design: Coördesign, Leiden

Lay-out: Crius Group, Hulshout

$\begin{array}{ll}\text { ISBN } & 9789463729215 \\ \text { e-ISBN } & 9789048544950 \\ \text { DOI } & 10.5117 / 9789463729215 \\ \text { NUR } & 685\end{array}$

(c) The authors / Amsterdam University Press B.V., Amsterdam 2021

All rights reserved. Without limiting the rights under copyright reserved above, no part of this book may be reproduced, stored in or introduced into a retrieval system, or transmitted, in any form or by any means (electronic, mechanical, photocopying, recording or otherwise) without the written permission of both the copyright owner and the author of the book.

Every effort has been made to obtain permission to use all copyrighted illustrations reproduced in this book. Nonetheless, whosoever believes to have rights to this material is advised to contact the publisher. 